\title{
Joseph Banks and William Hunter: Where the Royal Society meets the Royal Academy
}

The physician, anatomist and man-midwife, Dr William Hunter (1718-1783) and the gentleman-scientist, Sir Joseph Banks (1743-1820) shared similar objectives for the advancement of the natural sciences in the second half of the eighteenth century. Both men were naturalists, engaged in personal and organisational pursuit of collecting and disseminating various forms of early scientific information. While Hunter concentrated on developing anatomy as a form of useful knowledge, Banks's efforts centred on botany, a field of natural history crucial to Enlightenment ideas of improvement, of 'knowledge and social utility combined'. ${ }^{1}$ This essay describes their interconnected associations, affiliations and dealings, as patrons and collectors, and principal advisors in these emergent disciplines. Together, both Banks and Hunter contributed to Enlightenment views of public discourse surrounding the production of useful knowledge, in gathering and distributing the visual and material artefacts of exploration, forensic investigation, collation, and categorisation. Importantly, in their professional and personal activities both men highlighted developing forms of artistic practice and nascent theories of visual arts and how these would enhance and increase the circulation of natural knowledge. There is no doubt that Banks and Hunter exercised comparable approaches, supporting the integration of written descriptions and images, and how this aided comprehension but, as this essay suggests, their opinions often diverged on the methods and purposes of the visual arts, within a more generalised cultural sphere amongst members of the Royal Society and the Royal Academy of Arts, during the period.

\section{From Soho Square to Great Windmill Street}

As for many eighteenth-century collectors, Banks and Hunter prioritised finding individual houses in London where they could establish their museums. These Two 'centres of calculation' were situated within a short walking distance of each other, in the city of Westminster. ${ }^{2}$ (fig. 1 and fig. 2). The sites of both houses were located within the major developments taking place in London at this time, and typical of these re-designs of the city are John Gwynn's London and Westminster Improved, 1766, incorporating: 'new royal parks and palaces, open quays along the Thames with a new bridge, a grid of squares and thoroughfares, and the meticulously detailed straightening of the crooked streets and alleys of the old metropolis.' ${ }^{3}$ Gwynn's plans sought to articulate a response in urban design to the collaborative nature of economic and social conservativism, characteristic of both Banks's and Hunter's sense of Enlightenment improvement. ${ }^{4}$ Among the newly-paved, clean and well-lit streets of Westminster, Joseph Banks's house, 32 Soho Square, and William Hunter's home, 16 Great Windmill Street, dominated the corresponding cultural landscapes of natural history and anatomy, supplying a burgeoning early scientific community access to an increasingly dynamic range of resources. The homes of both men included impressive museums, libraries, and herbariums; with Hunter's house notable by the presence of a fully-integrated anatomical theatre. This essay describes how these closely interconnected, metropolitan, spaces reflected the many combined interests of the private worlds of Banks and Hunter and the goals of the public institutions which both men served.

Joseph Banks bought the lease to 32 Soho Square in 1777, following his return from the first of Captain Cook's voyages. He had previously rented a house nearby in New Burlington Street, which contained a 'perfect museum' but which, by the late 1770s proved to be too small to contain his growing collections ${ }^{5}$. The details of

1 John Cascoigne, Joseph Banks and the English Enlightenment: Useful Knowledge and Polite Culture, Cambridge University Press: Cambridge, 1994, p. 204.

2 See Bruno Latour, Science in Action, How to Follow Scientists and Engineers through Society, (Harvard : Harvard University Press, 1988), p.222. Latour's description of the accumulation and collation of knowledge during the Enlightenment era remains a useful model, distinguising a form of early laboratory practice often within domestic settings. I have described both houses in detail previously. See: Helen McCormack, William Hunter and his Eigtheenth-Century Cultural Worlds: The Anatomist and the Fine Arts, Routledge/Taylor \&Francis, 2018 and, Helen McCormack, 'Superb Cabinets or Splendid Anachronisms? Anatomy, Natural History and the Fine Arts in the London Town House', in The Georgian London Town House : Building, Collecting and Display, edited by Kate Retford and Susanna Avery-Quash, Bloombsury, London and New York, 2019, therefore only a brief mention of these houses is given in this essay.

3 Miles Ogborn, 'Designs on the City" John Gwynn's Plans for Georgian London, The Journal of British Studies, vol. 43, No. 1, Transforming Metropolitan London 1750-1960, University of Chicago Press, Chicago 2004, p. 15.

4 John Cascoigne, 1994, p. 186.

5 In December 1772, Gilbert White had visited Banks's museum in New Burlington Street and was impressed by the museum interiors. He describes a series of three large rooms, with each room containing an 'inestimable treasure'. Alongside the display of objects brought back from Cook's Endeavour voyage, there is, writes White, in the second room, 'a large collection of insects; several fine specimens of the bread \& other fruits preserved in spirits ... The number of plants is about 3000; 110 of which are new genera and 1300 new species.' The third room, contains an almost numberless collection of animals; quadrupeds, birds, fish, amphibia, reptiles, insects and vermes, preserved in spirits... Add to these the choicest collection of 
his will after his death in 1820, demonstrate how the collections had grown exponentially in the commodious apartments of 32 Soho Square. His librarian Robert Brown inherited use of the museum until his death, which was then bequeathed to the British Museum. The interiors of the house contained:

'My library, herbarium, manuscripts, drawings, copper plates, engravings and everything else in my collections usually kept in the back buildings of my house in Kings otherwise Soho Square and fronting on Dean street ....' ${ }^{6}$

Two illustrations by the artist Francis Boot (fig. 3 and fig. 4) show the interiors of Banks's museum at 32 Soho Square and the more personal space of his study. ${ }^{7}$ In his biography of Banks, Carter stresses the important role that 32 Soho Square played in the expansion of British interests in the emerging empire of the Southern hemisphere, referring to the house as the 'true birthplace' of the 'proposal for a settlement in New South Wales', for example. ${ }^{8}$ However, for the purposes of this essay, the relevance of 32 Soho Square is as an important 'academy' in the instruction of artists, engravers, and printers, alongside scientists. Explaining Banks's working arrangements with the many individuals he employed to care for his collections, catalogue, store, record, and conserve, the objects contained within, John Cascoigne has remarked that the house was, in effect, a home-cumresearch institute. ${ }^{9}$ Just as importantly, a group of artists worked consistently at Soho Square, making visual records of the products of Banks's research; in this sense, Banks's influence over developments in the visual arts of the period cannot be underestimated. Carter writes:

So, from the Autumn of 1777 , across the courtyard behind the house in Soho Square in the back premises under the herbarium, the engravers room became the scene for the last stages in preparing the plates for the florilegium.... For nearly five years this regime operated with Dryander increasingly important as curator of the herbarium and library and as a sort of supervising clerk of the artistic works. ${ }^{10}$

Among the artists working at 32 Soho Square, according to Carter were, Daniel Mackenzie, Gerhard Sibelius, Gabriel Smith; and in the employ of Banks more generally, John Frederick Miller, James Miller, John Cleveley, Frederick Polydore Nodder, Paul Sandby, James Sowerby and later, William Westall. ${ }^{11}$ Banks's main preoccupation was the accurate delineation of botanical specimens, and his preference for artists that demonstrated fidelity in draughtsmanship, such as Sandby, is well known; his patronage of others such as Johan Zoffany, reveal something of the scope of Banks's interest in the visual arts that involved more than simply an accuracy of drawing. ${ }^{12}$ Banks's concern for precision or 'truthfulness' in the production of images is repeated in several accounts of his dealings

drawings in natural history that perhaps every enriched any cabinet public or private; 987 plants drawn \& coloured by Parkinson, and 1300 or 1400 more drawn, with each of them a flower, a leaf, and a portion of the stalk coloured, by the same hand, besides a number of other drawings, of animals, fish, birds \&c. And what is more extraordinary still, all the new genera and species, contained in this vast collection are accurately described, the descriptions fairly transcribed, and fit to be put to the press. See Rashleigh Holt-White, The Life and Letters of Gilbert White of Selbourne 1720-1793, Vol. 1. J.

Murray, London, 1901, pp. 210-212. Harold B. Carter writes that there is no clear reason for Banks's move to 32 Soho Square but from Gilbert-White's description, the New Burlington Street house was crowded. He also remarks that the location itself was unfashionable at this period: Harold B. Carter, Sir Joseph Banks 1743-1820, British Museum (Natural History) London, 1988 p. 331. However, it is mentioned in Gwynn's plan, intended for future improvements, Gwynn, 1766, p. 85.

${ }^{6}$ The Last Will and Testament of the Right Honourable, Sir Joseph Banks, National Archives, PROB 11/1634/263, p.3.

7 Referred to by Banks as: '... the unarranged regularity of my little den', according to Harold B Carter. See Harold B. Carter, 1988, p. 173.

8 ibid, p. 216.

${ }^{9}$ Gascoigne, 1994, p. 70.

${ }^{10}$ Carter, 1988, p. 141.

${ }^{11}$ Carter provides details of the 'engravers' room', fitted up with eight presses with shelves and drawers, each press capable of storing 90-100 copper plates of botanical engravings. However, the room must have also served as a studio, where the artists could make copies and work up engravings from original drawings. Situated underneath the herbarium at 32 Soho Square, this room was connected to the basement of the main house; Carter, 1988, p336.

12 The source of this account of Banks's preference for 'accurate' drawing is the Diary of Joseph Farington, Kenneth Carlick and Angus Macintyre eds., 17 vols. New Haven and London, 1978-98, vol. 1, p. 113. See also, Paul Sandby, Picturing Britain, John Bonehill and Stephen Daniels eds., exh. cat. Paul Mellon Centre for Studies in British Art and the Royal Academy of Arts, London, 2009, p. 19. For an explanation of this period of Zoffany's career, see: Martin Postle, ed., Johan Zoffany RA Society Observed, exh. cat. Yale Center for British Art in association with the Royal Academy of Arts and Yale University Press, New Haven and London, 2011, p.31. 
and relationships with artists. For Bernard Smith, in European Vision and the South Pacific, despite Banks's close connection to some of the 'most learned and classical antiquaries and men of taste of the day', the naturalist was thought to reject contemporary aesthetics in the visual arts that favoured classical revival styles. ${ }^{13}$ Smith explains that Banks's views were formed by an understanding of artistic practice that centred on the writings of John Locke and cites the establishment of a drawing school at Christ's Hospital in 1693, as an example of the pedagogical beginnings of early Enlightenment forms of instruction in the arts. ${ }^{14}$ Such factual forms of drawing seemed in sharp contrast to the fashionable taste for copying classical antiquity and later Romantic approaches to the visual arts. As Smith has argued, explorations in the Pacific, undertaken and supported by Banks, cast a very different light on the aesthetics of European arts, particularly painting. The 'discoveries' in the Pacific challenged European values in this respect: 'where art as information and art as taste meet with significance for the future direction of painting. ${ }^{\prime 15}$ Banks is often identified as someone allied to the idea of art as information, and as Smith argues, his views on such approaches to the visual arts held significant influence by means of his long service as President of the Royal Society from 1778-1820, his election to the Dilettanti Society in 1774, and from his growing social and intellectual networks that were entertained in his house and museum at 32 Soho Square.

Most frequently cited as a formative influence on the young Joseph Banks is the naturalist and antiquarian, Thomas Falconer (1738-1792) ${ }^{16}$. The letters between Banks and Falconer dating from the early 1770 s provide an insight into the working methods of the illustrators employed by Banks, and under his direction, particularly during his voyage to Scotland and Iceland. Falconer was especially critical of travellers and explorers who relied on written descriptions and neglected to provide visual aids. This, he argued, created confusion and obfuscation, writing to Banks that Martin Martin's A Description of the Western Islands of Scotland (1703) was guilty of such inattention: 'For this reason, Martin and others have given us a false idea of the Western Islands ... What an assistance it is then to truth to have the objects delineated by one common measure which speaks universally to mankind'. ${ }^{17}$ Therefore, Falconer reinforced for Banks the efficacy of good, reliable images. Not only could such images provide information, they were also held to be infallible under intense scrutiny, to be a true or objective representation of the various places, people and climates encountered on these voyages. These ideas became increasingly important for early scientists and naturalists such as Banks and Hunter, as antiquarian working methods developed to incorporate close analysis of historical objects, as well as examination of historical texts. For example, John Gascoigne makes clear that Banks's direction for the Royal Society was guided by a 'Baconian view that science should take the form of useful knowledge', which, for members of the Society of Antiquaries and the Royal Society meant a forensic examination and practical observation of phenomena. ${ }^{18}$ Thus, close enquiry and recording of historical materials depended on first-hand accounts of physical encounters, particularly as these related to archaeology, geology, zoology, anatomy and other emerging natural sciences. While these 'Baconian' methods began to dominate the various activities of the Royal Society and the Society of Antiquaries, debates continued over the practicalities of such practices. ${ }^{19}$ As described further in this essay, these ideas proved to be crucial for Banks but especially for Hunter in his role as first Professor of Anatomy at the Royal Academy of Arts.

When Joseph Banks was elected President of the Royal Society in 1778, William Hunter had been successfully teaching anatomy from his home and museum at 16 Great Windmill Street, just off Piccadilly, for more than a decade, and been a member of the Royal Society and the Society of Antiquaries, London, since 1767; he had also been teaching anatomy to artists at the Royal Academy of Arts from its foundation in 1768. Joseph Banks and William Hunter were part of the network of early scientists in London during the second-half of the

\footnotetext{
${ }^{13}$ Bernard Smith, European Vision and the South Pacific: A Study in the History of Art and Ideas, Yale University Press, New Haven and London, 1985, p.13.

${ }^{14} \mathrm{Ibid}$. See also, James L Axtell (ed) The Educational Writings of John Locke, Cambridge University Press, Cambridge, 1968; Ann Bermingham, Learning to Draw: Studies in the Cultural History of a Polite and Useful Art, Paul Mellon Centre for Studies in British Art, New Haven and London, 2000.

${ }^{15}$ Bernard Smith, Imagining the Pacific in the Wake of the Cook Voyages, Yale University Press, New Haven and London, 1992, p.64. Smith articulates these different approaches to styles and aesthetics in the visual arts, as 'empirical naturalism' and 'classical naturalism', in the ways that artists distinguished a true representation from a more imaginative or fictional depiction.

16 John Bonehill, 'New Scenes drawn by the Pencil of Truth': Joseph Banks' northern voyage' in Journal of Historical Geography, vol. 43, 2014, p.9.

17 Thomas Falconer to Joseph Banks, $16^{\text {th }}$ January 1773, quoted in Smith, European Vision, 1985, p. 14.

18 Gascoigne, 1994, p.40.

${ }^{19}$ See Sam Smiles, Eye-Witness: Artists and Visual Documentation in Britain 1770-1830, Ashgate, Aldershot, 2000; In relation to William Hunter and antiquarian investigation, see: Helen McCormack, 'Dr Hunter's Shield: "Miscellaneous Curiosities" and Antiquarian Debates' in William Hunter's World: The Art and Science of Eighteenth-Century Collecting, E. Geoffrey Hancock, Nick Pearce and Mungo Campbell, (eds), Ashgate, Farnham and Burlington, 2015, pp. 240-246.
} 
eighteenth century that made up what John Gascoigne has described as the 'polite culture' of the English enlightenment. Both men shared memberships of the same learned societies and moved in similar, elite circles. Their cultural worlds centred on the highly-visible and industrious activities at Soho Square and Great Windmill Street, and at the various other locations situated in between, including the Royal Society, the Society of Antiquaries, and the Royal Academy, ranging from sites such as Crane Court to Old Somerset House, in the Strand. Their combined interests are characterised by the ways in which a metropolitan scientific community emerged in the 1770s, positioned around these two households. However, the destruction of both buildings and the subsequent dispersal of their contents, means that the significance they once held has been all but forgotten and the meanings of such domestic sites in the history of science more generally has been overlooked. ${ }^{20}$

In contrast to Sir Joseph Banks's home at 32 Soho Square, with its spacious rooms devoted to social gatherings, 16 Great Windmill Street functioned as a working anatomical school. Visitors to Hunter's house tended to show up for instruction in the museum and anatomical theatre. The polite 'philosophical breakfasts' and 'literary Saturnalia' that were a feature of life in 32 Soho Square were not recognizable in the activities recorded at Great Windmill Street. Most accounts of life in Hunter's house are from pupils from his anatomy school and of assistants Hunter employed to help in his museum and anatomy theatre, these include, among others, William Hewson (1739-1774), William Cruickshank (1745-1800) and William's brother, the surgeon, John Hunter (1728-1793), who adopted the architectural model of 16 Great Windmill Street for his own London house in Leicester Fields. The French physician and anatomist, Felix Vicq-d'Azyr (1748-1794), provides one of the most detailed descriptions of the interiors of 16 Great Windmill Street, demonstrating, perhaps that while Hunter's museum was well known to European visitors, it was less frequented by English writers. ${ }^{21}$ Of particular note among mentions of the collections at 16 Great Windmill Street, in the museum, were the display of the copper plates for the publication, The Anatomy of the Human Gravid Uterus (1774) Hunter's great atlas focusing on the development of the human fetus, and stages of childbirth. ${ }^{22}$ Importantly, the images for this publication highlight the integration of drawings taken from the life, and therefore demonstrate the kinds of ap proaches to objective, useful, knowledge that both Banks and Hunter endorsed; the artists being compelled to revivify the cadavers of numerous women who had died in childbirth and present them 'lifelike' again to the public. The Anatomy of the Human Gravid Uterus might be considered as the ultimate collaboration or combination of fine art production and medical knowledge, encompassing an accuracy and attention to detail called for by eighteenth-century naturalists, and embellished by precision in reproduction of its life-sized engravings. The work has been considered recently in a number of scholarly readings that foreground contemporary debates on the veracity of such image-making and in subsequent interpretations of their perceived inherent objectivity. ${ }^{23}$ While an emphasis on re-interpreting or reassessing The Anatomy of the Human Gravid Uterus provides numerous valuable insights into eighteenth-century notions of 'useful knowledge' and of studies 'taken from the life', the display of the copper plates for this publication in Hunter's museum demonstrate how these images circulated in a network of information centred on Windmill Street and its surrounding environs as a cultural landscape. In this sense, while Ludmilla Jordanova is correct to describe the atlas as a sophisticated layering of images and texts, which are 'varied and intricate', part of its variation and intricacy, it might also be suggested, are the ways in which such images became integrated within Hunter's teaching more generally, particularly to students at the Royal Academy of Arts. ${ }^{24}$ Therefore, much of the significance of The Anatomy of the Human Gravid Uterus, of its reliance on

20 Donald L Opitz et al, Domesticity and the Making of Modern Science, (Basingstoke and New York: Palgrave Macmillan, 2016, p.2. The exception to this being, perhaps, Steven Shapin, 'The House of Experiment in Eighteenth-Century England', 1988, Isis, vol. 79. No. 3.

21 Vicq d'Azyr, Eulogie in Oeuvres de Vicq d'Azyr, receullies et publics avec des notes et un discours sur sa vie et ses ouvrage, par Jacques L. Moreau (de la Sarthe), vol II, (Paris 1805) pp. 352-388; St James's Chronicle, May 25th, London, 1779.

22 Johann Christian Fabricus, Briefe aus London vermischten Inhalts, Dessau, Leipzig, 1784. Fabricius gives a detailed description of the interiors of Hunter's museum, commenting on the display of the 'fine large, engraved copperplates of the Uterus', pp. 75-94.

${ }^{23}$ See Meredith Gamer, 'Scalpel to Burin: A Material History of William Hunter's Anatomy of the Human Gravid Uterus', in William Hunter and The Anatomy of The Modern Museum, Mungo Campbell and Nathan Fils, eds., Yale Center for British Art, New Haven, The Hunterian, University of Glasgow, Yale University Press, New Haven and London, 2018, pp. 109-126. Also, Lorraine Daston and Peter Galison, eds., Objectivity, Zone Books, New York, 2007, pp. 74-77; Harry Mount, 'Van Rymsdyk and the Nature-Menders: An Early Victim of the Two Cultures Divide', British Journal for Eighteenth-Century Studies, vol. 29, 2006, pp. 79-96; Sam Smiles, Ashgate, 2000, pp.13-23; Ludmilla Jordanova, 'Gender, Generation, and Science: William Hunter's Obstetrical Atlas' in William Hunter and the Eighteenth-Century Medical World, W.F. Bynum and Roy Porter, eds., Cambridge, Cambridge University Press, 1985 pp. 385-142.

24 Jordanova, 1985, p.399. The anatomy of the human gravid uterus was explained by Hunter as part of his series of lectures in anatomy more generally. In the preface to The Anatomy of the Human Gravid Uterus, he explains how: 'he has constantly explained his observations on this subject in his public lectures', Hunter, 1774, p.6. 
images and text, was also supported by spoken word, in public lectures which Hunter conducted in his capacity as first Professor of Anatomy at the Royal Academy of Arts, as well as his anatomy theatre at Windmill Street. There is some value then in reading Hunter's Two Introductory Lectures, published posthumously, alongside the manuscript of lectures to students at the Royal Academy and the preface to the Anatomy of the Human Gravid Uterus, in order to gain a fuller understanding of how such a work is distinguished, generating meanings of cultural importance during the period. ${ }^{25}$ For example, The title page to The Anatomy of Human Gravid Uterus, mentions Hunter's position as Professor of Anatomy at the Royal Academy of Arts as second only to his status at court as Physician in Extraordinary to the Queen, indicating the prominence that he wished to place on his performance as a public orator and teacher of anatomy to artists.

One painting, Johan Zoffany's Dr William Hunter lecturing at the Royal Academy, c.1772, (fig. 5) demonstrates this role explicitly and in many ways corresponds with Benjamin West's full-length portrait of Sir Joseph Banks, 1771 (fig. 6). Both paintings were executed as arrangements were being made for Cook's second voyage to the Pacific. The portrait of Hunter was left unfinished, as Zoffany had to leave for Italy, rather than his planned travel alongside Banks to the Pacific, under commission from Queen Charlotte to record, among other things, the Tribuna, (or interior) of the Uffizi museum in Rome. ${ }^{26}$ In this respect, both paintings reflect the interconnections between art, anatomy and natural history at a specific historical moment, as the objects (natural and artificial) and people encountered in imperial explorations, were circulated among a metropolitan audience. In recent years, the portrait of Banks has attracted considerable attention from scholars, providing important insights into the composition, style and performance of the sitter. Surrounded by his 'riches' brought back from the first Cook voyage, the selection of objects that appear in the portrait of Banks, include many items understood as 'exotics' during the period and the prominence of Banks's finger, touching edge of a flax Maori cloak, testifies to the authenticity of his expertise: 'the first hand and intimate experience that informs knowledge.'27 Added alongside these objects is a copy of a drawing of flax, situated at Banks's feet, reiterating the ways in which he promoted the recording of natural knowledge. In a similarly animated portrayal, Johan Zoffany presents William Hunter mid-lecture to a group of Royal Academicians. Hunter is poised to touch the living model, just as the Banks portrait is testimony to his intimate and first-hand knowledge, the artist intimates in this image of Hunter, the anatomist with the subject of his own expertise, the human body. Perhaps, as an unfinished work, this painting of Hunter has received less attention from scholars, despite the fact that it is a rare image of a lecture at the Royal Academy of Arts in its early days. A number of the sitters are clearly identifiable, including, most prominently, Sir Joshua Reynolds, seated left of centre, holding his ear-trumpet. ${ }^{28}$ Comparing these paintings that exhibit a dynamic or active subject enthusiastically demonstrating profound familiarity with their own specialist subjects, provides tangible clues as to the close association between Joseph Banks and William Hunter at this time.

\section{Naturalism: Empirical and Autopsia}

The similarities of approaches to the delineation, circulation and production of knowledge between Joseph Banks and Hunter originate in somewhat different or separate traditions. By the 1770s, these artistic or procedural conventions began to align or converge under new methods undertaken by antiquarian investigations, which were assimilated within the practices adopted by the Royal Society, particularly under Banks's presidency. However, antiquarian interests had been foregrounded by a generation previous to Banks and Hunter, and ideas of accuracy and fidelity, in truth to nature, were expounded by medical practitioners especially in practices of autopsia, or 'to see with one's own eyes.'29 In many ways, anatomical ideas of autopsia corresponded to

\footnotetext{
25 William Hunter served as first Professor of Anatomy at the Royal Academy of Arts from 1768 until his death in 1783. His lectures to students at the RA exist in manuscript form but these are only a very small proportion of the lectures he must have delivered there over the course of his fifteen-year tenure. Inevitably, this means, that his role in the RA is often overlooked in studies of his anatomical teaching.

26 Postle, 2011, p.31.

27 See Harriet Guest, 'The Great Distinction: Figures of the Exotic in the Work of William Hodges' in Oxford Art Journal, Oxford University Press, vol. 12, No 2 (1989), p.42. Also, Nicholas Thomas, Entangled Objects: Exchange, Material Culture and Colonialism in the Pacific, Harvard University Press, Harvard, 1991, p. 143.

28 See Postle, 2011, p.31. Also, McCormack, 2018, pp. 141-151.

${ }^{29}$ For an overview of the work of early antiquarian and medical specialists, see Craig Ashley Hanson, The English Virtuoso, Art, Medicine and Antiquarianism in the Age of Empiricism, University of Chicago Press, Chicago, 2009. See also, McCormack, 2018, pp. 19-46; The conventions of autopsia have a long tradition in medical history but perhaps are typified in this period by the work of William Harvey (1578-1657). William Harvey, Exercitatio anatomica de motu cordis et sanguinis in animalibus, Frankfurt, 1628, SpColl Hunterian Ac. 4.18; Andrew Wear, 'William Harvey and the Way of the Anatomists', History of Science, vol. 21, no.3, 1983, pp. 223-49; Philip Salman, 'William Harvey and Art Misplaced', Annals of Science, vol. 49, 1992, pp. 3-19.
} 
eighteenth-century notions of authenticity and truth to nature in the representation of objects of natural history in the visual arts. Therefore, William Hunter's training, as with other medical practitioners, had already embedded an idea of naturalism in the fine arts that appeared to concur with contemporary opinions of objective record. As Joseph Banks directed the work of Sydney Parkinson (1745-1771) and, perhaps to a lesser extent, William Hodges (1744-1797), Hunter also established a working relationship with artists he commissioned that, at times, seemed to be instructional, perhaps dictating to artists the final outcome. ${ }^{30}$ This type of influence over artistic works is evident in the comments from George Forster (Johann Georg Adam Forster) (1754-1794) who travelled on the second Cook voyage. Remarking on Hodges' interpretative treatment of some of his own sketches:

But it is greatly to be feared, that Mr Hodges has lost the sketches and drawings which he made from Nature in the course of the voyage, and supplied the deficiency in this case, from his own elegant ideas' ${ }^{31}$

Such intervention might also be considered as collaboration, however, and William Hunter's patronage of George Stubbs (1704-1806), provides a useful comparison. During the early 1770s, Hunter was engaged in research on comparative anatomy. He commissioned Stubbs to paint two animals that had been brought to London, the Nylgai (1769) (fig. 7), in the possession of Queen Charlotte and the other, The Moose (1770) (fig. 8), belonging to the Duke of Richmond. Hunter tellingly remarks that The Nylgai was painted by Stubbs 'under my eye', inferring a collaboration between artist and anatomist. ${ }^{32}$ While Stubbs's Nylgai formed the basis of Hunter's paper presented to the Royal Society in 1771, his researches on the moose were not published and existed as manuscript notes only for many years. Remaining in such obscurity, therefore, The Moose, appears to be an unlikely exemplar of the sublime works by Stubbs referred to by the naturalist, Thomas Pennant's in British Zoology, where he refers to Stubbs as: 'an artist not less happy representing animals in their still moments, than when agitated by their furious passions, his matchless paintings of horses will be lasting monuments of the one and that of the lion and panther the other'33. It is possible, therefore, that The Moose might also be considered amongst Stubbs's pioneering works of animal painting as it demonstrates the artist's keen knowledge of comparative anatomy, zoology and natural history in the rather somber and solitary image of the Moose, or Canadian Elk.

Hunter was particularly intrigued by theories of extinction and his manuscript notes explain how he was keen to distinguish this animal from the Irish Elk, a similar animal, whose fossil remains had been found in bog sites in Ireland and which Hunter believed to be extinct. Invited by General Carleton, a future Governor General of Canada, to examine the animal, Hunter instructed Stubbs to 'get a picture of it made', commenting that 'no pains was spared by that great artist to exhibit an exact resemblance both of the young animal itself, and of a pair of Horns of the full grown Animal'. ${ }^{34}$

It seems clear that Stubbs' paintings for Hunter are more than scientific images, they incorporate stylistic aesthetics in line with ideas of the sublime in nature. ${ }^{35}$ For this reason, Stubbs' paintings of animals during this period are often difficult to categorise, positioned in a space between 'Neoclassicism' and Romanticism, they are, in fact, deeply embedded within empirical, scientific, knowledge of the late eighteenth-century. Joseph Banks also commissioned Stubbs to depict two animals that were imported from the first Cook voyage, The Kongourou from New Holland, 1772, (fig. 9) and Portrait of a Large Dog, 1772 (fig. 10), both now in the National Maritime Museum, Greenwich. Again, both paintings correspond to the intense interests shared by Banks and Hunter at this specific historical moment. Stubbs' paintings captured the first images of these animals in Western art, and Banks exhibited them at his house in New Burlington Street, and then at 32 Soho Square, just as Hunter must have had his Stubbs' pictures on display at 16 Windmill Street; the paintings were bequeathed, along with the rest of

\footnotetext{
30 For the most recent overview of the work William Hodges, in particular, see: John Bonehill and Geoff Quilley, eds. William Hodges (1744-1797) The Art of Exploration, exh. cat. National Maritime Museum, Greenwich and Yale University Press, New Haven and London, 2004.

${ }^{31}$ Forster quoted in Smith, Imagining the Pacific, 1992, p. 72.

32 William Hunter, 'An Account of the Nyl-ghau, an Indian Animal not hitherto described', Philosophical Transactions of the Royal Society of London LXI, 1771, pp. 170-181; William Hunter manuscript notes, University of Glasgow SpColl, H146(13) to H.150(10): See, also, Helen McCormack, 'Pennant, Hunter, Stubbs and the Pursuit of Nature' in Enlightenment Travel and British Identities: Thomas Pennant's Tours in Scotland and Wales, Mary-Ann Constantine and Nigel Leask, eds., Anthem Press, London and New York, 2017, pp. 203-222.

33 Thomas Pennant, British Zoology, Warrington,1776-1777, p. 43.

34 Hunter, University of Glasgow SpColl, H.150(10).

35 McCormack, 2017, p. 212; Jenny Uglow, 'Stubbs and the Exotic' in 'all done from nature': George Stubbs, exh. cat., MK Gallery Milton Keynes and the Mauritshuis, The Hague, in association with Paul Holberton Publishing, London, 2019, pp. 35 52.
} 
Hunter's collection, to the University of Glasgow and remain in the Hunterian collection. These works were interchangeable, performing, on the one hand, the role of scientific description, so much so that Hunter was able to carry The Nilgai with him to demonstrate the animal's appearance while he read his paper to the Royal Society, in 1771, yet elaborate and detailed to such an extent that Stubbs' anthropomorphised creatures still manage to evoke sympathy and empathy from their viewers. ${ }^{36}$

Images such as these have been described by Bernard Smith as 'empirical naturalism', they are distinguished, Smith argues, by their lack of 'classical naturalism', works of art which follow the conventions of European art historical styles. He writes:

English art of the second half of the eighteenth-century recalls the empirical, naturalistic interests of so much Italian art of the $15^{\text {th }}$ century before it was folded over into the hard crusts of grandeur of the High Renaissance and Baroque styles. ${ }^{37}$

Besides Hunter's patronage of artists such as Stubbs, his collection encompassed a number of old master paintings that establish his interests in naturalism as this was understood more generally in the period. As Smith states, later eighteenth-century artworks in Britain sought to emulate or follow earlier schools of painting, particularly from the European high renaissance and baroque. In 1771, Hunter bought a selection of paintings from his friend, the artist, Sir Robert Strange (1721-1792). ${ }^{38}$ Strange, a fugitive after the defeat of the Jacobites at Culloden in 1746 , used his powerful connections in Italy to gain access to some of the more obscure and remote works of art, derived from the Northern Italian schools. These works were considered by British connoisseurs to relate closely to the advances in empirical science in the universities of the north of Italy, such as Parma, Padua, Milan and Bologna. The writer, critic and collector, Horace Walpole, remarked that the Bolognese school of painting, added 'to the dignity of the antique, join'd all the beauty of living Nature'. ${ }^{39}$ Strange's preface to his sales catalogue of 1769, explains how he sought out these works that seemed less well known than the Raphael's of the Sistene Chapel, for example. The value of such works lay in their obscurity but also in their connections for many collectors, such as Hunter, to the kinds of experimental science which happened during the fifteenth and sixteenth centuries in that part of Italy. For example, Strange describes a meeting during his travels with the famous anatomist, Ercole Lelli (1702-1766), who progressed the development of écorché models for the use of anatomical teaching. ${ }^{40}$ Therefore, 'empirical naturalism' for naturalists such as Banks and Hunter were profoundly integrated within the meanings derived from experimental, natural philosophy. Paintings in Hunter's collection, acquired from Strange's sale, for example, are typical of this Northern Italian style, composed of large, life-sized subjects, and a restrained form of Catholic imagery. For Hunter, these old master paintings belonged to a tradition of empirical research, epitomised for the anatomist by Leonardo da Vinci. ${ }^{41}$

Joseph Banks sought to influence his ideas on naturalism, on the forms of empirical naturalism, by careful selection and control of the artists he employed but it seems that Banks may have been reluctant to allow his draughtsmen unlimited freedom. ${ }^{42}$ For example, Carter writes that:

In spite of the possibilities opened by the aquatint experiments of Paul Sandby and Peter Burdett, Banks kept his engravers steadily at work exploring the virtuosity of pure line as the prime means of capturing the nuances of shadow and surface texture in seeking an exact pictorial record of a plant's essential structure for the purposes of botanical taxonomy. ${ }^{43}$

In contrast, Hunter appears to encourage a deeply experimental approach to the imitation of nature that reaches beyond mimesis, employing a number of important techniques and methods, originating in his study of forms of anatomical art, printing effects, knowledge of perspective and scale, and of the significance of the life class for the study of the human body. However, while Banks may not have openly encouraged artistic freedom, or artists' own elegant ideas, his tastes are, at times, expressed in identifiably romantic aesthetics, particularly, as Carter

\footnotetext{
${ }^{36}$ McCormack, 2017, p. 214, Uglow, 2019, p. 48.

37 Smith, 1992, p.63.

38 Robert Strange, A Descriptive Catalogue of a Collection of Pictures, selected from the Roman, Florentine, Lombard, Venetian, Neapolitan, Flemish, French and Spanish Schools, wo which are added, Remarks on the Principal painters and their works, Collected and Drawn during a journey of seven years in Italy, by Robert Strange, London 1769, University of Glasgow SpColl. H.7.8.

${ }^{39}$ Horace Walpole, Aedes Walpolianae, London, 1742, p.78-9.

40 See McCormack, 2018, pp. 122-123.

${ }^{41}$ Hunter refers to Leonardo as the 'best anatomist and physiologist of his time': Hunter, Two Introductory Lectures delivered by William Hunter to his last course of Anatomical Lectures at his Theatre in Windmill Street, London, 1784, p. 35.

${ }^{42}$ Smith, 1992, p. 63.

${ }^{43}$ Carter, 1988, p. 140.
} 
remarks, he expanded his network of artists to encompass, not just Paul Sandby but Nathanial Dance, William Parry, and Sir Joshua Reynolds. On his voyage to Iceland, passing near the Morven peninsula, on the West coast of Scotland, Banks was so moved by the scenery that he recalled the poems of Ossian and wished that he could stop to read these works under the shade of the Scottish woods. ${ }^{44}$ Recent scholarship on Sir Joseph Banks has sought to encompass his varied interests among a range of cultural practices, including the fine arts but, as with William Hunter, his activities as an art collector or patron of the arts continues to be obscured by his role as President of the Royal Society, his working relationship with the Royal Academy of Arts is also less well known. Clearly, as a member of the Dilettanti Society, and a patron of the Royal Academy of Arts, Banks is a crucial figure in the eighteenth-century art world. The Dilettanti Society has been the focus of more recent studies that attempt to reassess its activities and to explain its ambiguous nature between amateurish interests and informed connoisseurs. There is evidence that the Dilettanti Society had a serious purpose, funding a number of ventures during the second-half of the eighteenth century to rescue and record artworks and antiquities, and the sponsorship of individual classical-revival architects such as James 'Athenian' Stuart. The ultimate objectives of the Dilettanti Society may have been very different to those of the public-facing Royal Society or the Society of Antiquarians but their shared interests span a number of important cultural activities during the period, not least of which was the support and dissemination of artistic ideas in exhibitions, publications and commissions. ${ }^{45}$

\section{Civic Man and the Science of man}

Assembling such interrelated groups to which both Banks and Hunter were associated recalls the description of the culture of this period which John Gascoigne has referred to as: 'a set of often barely conscious social attitudes which coloured the values and actions of society.' ${ }^{46}$ However, enlightenment attitudes that permeated conversations among naturalists and dominated an increasingly visual discourse by the late eighteenth century, valued the prowess of autopsia, together with first-hand accounts, corroborated by eye-witnesses. This contributed to a scrutiny of the visual record and attempted to combine fine art theory alongside the weightier philosophy of Scottish enlightenment thinkers such as Adam Smith in the 1760s with his formulation of a stadial development of human society and Lord Kames' Sketches of the History of Man in the 1770s that articulate a familiar scenario of societal progress from barbarism to commercial civility. ${ }^{47}$ Therefore an interest in the history of the development of the human species grew alongside a history of the earth itself, with anatomy and natural history more generally providing new and experimental information. Among the polite culture of London's newlyfashioned west end, these ideas were played out by both Banks and Hunter in the ways described by Gascoigne and others. One incident from the period might serve to illustrate this. In his Two Introductory Lectures, William Hunter describes a visit to his anatomy theatre, in 1771, by Joseph Banks, accompanied by Omai, the young Pacific Islander brought to Britain by Captain Tobias Furneaux on his ship HMS Adventure on its return from the second voyage by Captain Cook. Omai spent two years in London, he was painted by Sir Joshua Reynolds and William Hodges, each providing very different impressions of their sitter, and taken by Banks to meet the King and Queen, among other important figures in the city. ${ }^{48}$ (fig. 11 and fig. 12) In Hunter's account, Omai: 'manifested a great curiosity of desire of having the functions of the internal parts of the body explained to him'. ${ }^{49}$ As Harriet Guest and others have described, the display and public performance of Omai, raises problems in relation to the kinds of ways in which the production of knowledge was gathered by Banks and Hunter. For example, Omai seems to have been considered as a curiosity rather than an individual, subject to the same treatment and categorization as the 'riches' that surround Banks in his portrait by West. ${ }^{50}$ Such accounts reflect the contradictions in enlightenment values that sought to understand the history of human development but which equally appeared

\footnotetext{
44 John Bonehill, 'New Scenes drawn by the Pencil of Truth': Joseph Banks's Northern Voyage, Journal of Historical Geography, 43, 2014, p. 12.

45 Jason M. Kelly, The Society of Dilettanti, Yale University Press, New Haven and London, 2010.

${ }^{46}$ John Gascoigne, Science in the Service of Empire: Joseph Banks, the British State and the uses of Science in the Age of

Revolution, Cambridge University Press, Cambridge, 1998, p. 202.

47 Ibid.

48 Hunter, 1784, p.6; See also, EH McCormick, Omai: Pacific Envoy, OUP, Australia and New Zealand, 1977. For recent interpretations of the portraits of Omai, see: Harriet Guest, 'Curiously Marked' in Empire, Barbarism, and Civilisation: Captain Cook, William Hodges and the Return to the Pacific, Cambridge University Press, Cambridge, 2007, pp. 68-90; Guest, 1989, pp. 48-52; Quilley and Bonehill, 2004, pp. 134-135; Nicholas Thomas, 'A Great Collection of Curiosities from the South Sea Islands' in Campbell and Fils, eds., 2018, pp. 143-157. For a survey of Reynolds's portraits, including Omai, see Martin Postle, Joshua Reynolds: The Creation of Celebrity, Tate Publishing, London, 2005.

49 Hunter, 1784, p.6.

50 Guest, 2007, p. 69.
} 
to objectify the differences that marked human species. For the purposes of this essay, in Hunter's recollection of his encounter with Omai, he appears empathetic towards the cultures of the 'South Sea Islanders', acknowledging their own 'wild anatomical \& physiological knowledge', acquired without 'the assistance of letters'. ${ }^{51}$ Despite its expression in European-centric language, Hunter's intention seems to be to recognise that knowledge of anatomy is acquired and exists historically in many periods and cultures. Describing this meeting with Omai in his lectures, is intended to incorporate the South Sea islanders' own knowledge of anatomy alongside other: 'men of curiosity, observation, experience and reflection, [who] could not overlook an instance of natural organisation, which was so interesting and at the same time so wonderful; more especially much of them as applied to the study and cure of diseases'. ${ }^{52}$

The presence of Omai in Hunter's museum makes explicit the connections between Banks and Hunter, along with the other portraits described in this essay, Omai, the person, is a crucial figure, in this respect, in the network of individuals, organisations and public institutions that populated the cultural landscape of eighteenthcentury London. However, there is a distinction that might be useful to apply in assessing or reviewing the approach to the cultural activities of Banks and Hunter. As mentioned at the beginning of this essay, their homes formed significant and important sites of scientific research during the late eighteenth century, a fact that is often overlooked in histories of science, and while Gascoigne has described these sites as increasingly anachronistic, as the powerful bureaucratic British state encroached on the private pursuit of natural knowledge, both Banks's and Hunter's collections appear to have retained important and relevant significance. ${ }^{53}$ Nonetheless, as individuals, rather than resenting state intervention in social policy towards the development of science, as Gascoigne has explained of Joseph Banks, Hunter welcomed the concept of state support and sponsorship, in tune with his own ideas of a beneficent government, functioning at the level of civic generosity, a particularly Scottish aspect of enlightenment philosophy that accentuated an individual's civic role. Hunter had petitioned King George III for a public school of anatomy before he built his own, and in his activities as a public lecturer, he often addressed topics of public concern, beyond anatomical teaching. ${ }^{54}$ Whereas, Banks sought to retain his retinue of private, intimate relationships in carrying out his research and governance of the Royal Society, for example, as described by Gascoigne. Perhaps Hunter's background in early Scottish enlightenment philosophy, his exposure to philosophers such as Francis Hutchesson (1694-1746) as a young man, and his continued friendship with David Hume, the artist Allan Ramsay and others, impressed on him the sense of public service as a civic duty, not a private privilege. In this sense, Sir Joseph Banks and Dr William Hunter may have been motivated by very different approaches to the pursuit and expansion of natural knowledge.

\footnotetext{
51 Hunter, 1784, p.6.

$52 \mathrm{lbid}$.

53 Gascoigne, 1998, p. 199.

54 McCormack, 2018, p.139-142.
} 